\title{
Polder Politics Under Pressure: The Advisory Roles of Political Scientists in the Netherlands
}

\author{
Valérie Pattyn and Arco Timmermans
}

\subsection{The Embedding of Advisory Roles}

In this chapter we analyse the policy advisory activities of political scientists in the Netherlands, all working from their academic home basis. In the Netherlands, public administration (including public policy) exists alongside political science. At some universities the two strands of the discipline are integrated, but often they are organized in separate departments and have separate research and education programmes. Does this segmented nature of political science in the Netherlands appear in the external activities of those scholars concerned? Or is the overall policy advisory system in which political scientists are embedded or placed in some way, a more important overarching institutional determinant? What about developments in the policy advisory system itself, pressures on institutions and trends in the environment and their consequences for the supply and demand of scholarly political science advice? These are the central questions we shall be examining in this chapter. We present two

V. Pattyn $(\bowtie) \bullet$ A. Timmermans

Institute of Public Administration, Leiden University, Leiden, The Netherlands e-mail: v.e.pattyn@fgga.leidenuniv.nl; a.timmermans@fgga.leidenuniv.nl

(C) The Author(s) 2022

M. Brans, A. Timmermans (eds.), The Advisory Roles of Political

Scientists in Europe, https://doi.org/10.1007/978-3-030-86005-9_13 
hypotheses on how these structural and cultural factors related to the Dutch policy advisory system may affect the types and magnitudes of political-science-based advising. First, we expect experts and opinionating scholars to be the most frequent categories of advisor, given the multiple institutional and informal access points in the Dutch consensus-style policy advisory system. Second, we expect the segmented structure of political science to be visible in advisory profiles, with political scientists 'senso strictu' being more active as opinionating scholars while public administration scholars more often play the role of expert.

To set the stage, we first present the historical and institutional development of the academic discipline of political science in the Netherlands. Then we look at the main features and trends of the Dutch policy advisory system and the niche occupied by political scientists. While a niche may assume some demarcated space in the larger tree, it also may be that academic political scientists are included in more diffuse ways in advisory processes. One reason why this may be is that political science not only has a substantive, material object of knowledge of its own but also squares into many other fields of knowledge where political or administrative dimensions come in view. For example, ecologists and experts of artificial intelligence profile for their substantive knowledge but political scientists may appear in advisory roles related to these areas whenever political decision making on renewable energy or administrative responses to algorithms for data analysis are at stake. Likewise, scholars of public policy mostly profile on the governance of problems, mixing knowledge of policy processes with content.

The empirical findings based on the survey are the central part of this chapter. They help us to draw the picture of advisory activities and views on them within the Dutch scholarly political science community. As we will see, political scientists in this country gauge their visibility and their social and political impact as relatively high, and a large majority of them engage in policy advisory or advocacy activities, either occasionally or more frequently, in a way more or less visible to a wider audience. The patterns that emerged also indicate the extent to which the segmented structure of academic political science impacts advisory roles, and the significance and prospects of such segmentation for the years to come. We conclude by examining some implications of our findings and offering our views on possible future developments. 


\subsection{The Institutionalization of Political Science in Dutch Academia}

Political science in the Netherlands has a long tradition and a history of institutionalization. As far back as 1613, Daniel Heinsius was appointed Professor of Politices' at Leiden University. However, the real emergence of political science in the Dutch academic system came in the years after the Second World War. The first three full chairs in political science were established between 1948 and 1953. Jan Barents, the holder of the first Dutch political science chair at the University of Amsterdam, was a member of the executive committee of the International Political Science Association and also co-founder of the Dutch Association of Political Science (Nederlandse Kring voor Wetenschap der Politiek) in 1950. In 1963, the first professor of political science to have an educational background in political science was appointed (Reinalda, 2007), and in 1967, political science was included in the Dutch Academic Statute governing university education in the Netherlands (Reinalda, 2007). In later years, other universities followed suite by setting up departments of political science and public administration. In 1973, the Association of Public Administration (Vereniging voor Bestuurskunde) was founded. The main academic journals published in the field emerged concurrently with the first chairs and associations: Bestuurswetenschappen in 1946, the Internationale Spectator in 1947, Acta Politica in 1965, and Beleid o Maatschappij in 1973. Later, in 1992, the Dutch Association of Public Administration launched its own journal, Bestuurskunde.

Within academic departments, political science developed as a broad discipline together with public administration and, to a lesser extent, public policy and grew into separate research and education programmes. Of the 14 universities in the Netherlands, 10 have a department of political science or of public administration, or both. In total there are 14 departments in the field. Political science and public administration mostly coexist in separate institutes and programmes, reflecting a segmented institutional structure. Most departments are members of the Netherlands Institute of Government (NIG), which organizes conferences, facilitates research mobility, and runs a joint $\mathrm{PhD}$ education programme. The existence of this national $\mathrm{PhD}$ programme is a feature not seen in most other countries and may indicate that attempts are being made to coordinate the segmented world of academic political science in the Netherlands. There is a high degree of mobility of political science scholars between Dutch 
universities, perhaps not for this reason alone, while the discipline generally boasts an international orientation. The student population in political science has increased and internationalized, in particular since the turn of the century.

The survey comprising the Netherlands revealed (for the count year 2018 ) the presence of 457 scholars in the field with a $\mathrm{PhD}$ degree, affiliated to one of the 14 university departments where political science teaching and research is organized structurally. This number does not include teaching staff without a $\mathrm{PhD}$ or $\mathrm{PhD}$ researchers.

\subsection{The Dutch Policy Advisory System}

The Netherlands is commonly considered a text-book example of a consensus-driven, neo-corporatist country (Lijphart, 2012). Consensus politics has proven to be a strong mechanism with which to overcome the segmentation of the Dutch political landscape and its underlying socioeconomic and religious cleavages. It has given rise to the establishment of politico-administrative arrangements that make the involvement in policy making as broad as possible. The consensus-oriented character of Dutch democracy has been a determining factor in the configuration of the country's policy advisory system, and in the role of expertise in general. Expertise in consensus countries is broadly valued for providing a nonpartisan basis for political agreement and for depoliticization (Van Nispen \& Scholten, 2015). It has permitted the establishment of a rich, densely populated landscape of relatively independent institutions specialized in policy analysis. In the Netherlands, these public knowledge bodies combine subject-specific research with the provision of knowledge-intensive services (Koens et al., 2016).

Unique to the Netherlands are the so-called planning bureaus, comprising the Netherlands Institute for Social Research, the Netherlands Bureau for Economic Policy Analysis, the Central Bureau of Statistics, the Environmental Assessment Agency, and the high-level Scientific Council for Government Policy (WRR). Most of these planning bureaus are strongly oriented towards evidence-based advising (Halffman, 2009), and the WRR is also an important source of policy ideas (Van Nispen \& Scholten, 2015). Since the establishment of the Dutch Constitution in 1814, the Netherlands has had a National Court of Audit whose historical roots go back even further, to the fifteenth century. Audit courts for governmental policy evaluation were set up at local level in the early 2000 s. 
Most of these are advised by external experts. External advisory organizations focusing on the structure and working of government itself include the Council for Public Administration, and the Electoral Council, with the latter focusing specifically on electoral processes and systemic issues. Within the domain of international affairs and domestic security, the Advisory Council on International Affairs and the National Coordinator for Security and Counterterrorism provide strategic knowledge and policy options. All of these institutions perform a strong demarcation function, not only bridging the gap between science and politics, but often also establishing the boundaries within which political debate takes place (Halffman \& Hoppe, 2004). As such, the advisory bodies and councils have always had a rationalization and legitimation function. Generally speaking, the expert rationality of authorized institutional representatives is highly valued (Strassheim \& Kettunen, 2014). Also, most political parties have their own scientific bureau (Timmermans et al., 2015), although the influence of such is somewhat limited (Pattyn et al., 2017).

Consensus democracy in the Dutch case has been typically associated with a neo-corporatist tradition, characterized by the institutionalized involvement of representatives of all relevant segments of society (such as trade unions and employer organizations) in policy decisions (Crepaz \& Lijphart, 1995). While the neo-corporatist characteristics of the country have weakened in recent years, the features of the so-called polder model (i.e. tripartite cooperation between employers, trade unions, and government) in the Netherlands are still visible in the influential role that the Socio-Economic Council plays in welfare state discussions and labouremployer negotiations and in the institutionalization of a wide range of strategic and technical advisory bodies that focus on specific policy areas. Although the number of such advisory bodies has significantly fallen since the 1990s (down from 119 to 24 official advisory bodies at national level), they still constitute a cornerstone of the Dutch advisory system (Scholten \& Van Nispen, 2015). Academics participate in many of these advisory organizations on a rotating basis. In several of them, such as the abovementioned Council for Public Administration and the Electoral Council, political scientists are the most important temporary members.

The institutionalization of policy advice in the Netherlands is not limited to the establishment of formal and vested advisory organizations and corporatist-style advisory bodies. A series of other arrangements exist by which academics can provide input to policy making. Several regulatory guidelines require the involvement of experts. For formal policy reviews, 
for instance, an expert must be appointed to the advisory committee (Regeling Periodieke Beleidsevaluatie 2017). Furthermore, where such legal requirements do not exist, it is common practice to involve academic experts in advisory committees concerned with applied research, including policy evaluations. The relatively large number of 'endowed professorships' in Dutch academia, for which the funding and appointment of chairs is supported by external parties, is also important. The latter parties may be foundations or private actors, but also ministries or non-profit organizations. Such provisions have contributed to the anchorage of academic expertise within the public sector and to more permeable boundaries between academia and advisory structures.

To sum up then, when viewed in terms of the locational model presented in Chap. 2, evidence-based knowledge in the Dutch system is imported and embedded at the intersections of the government arena, the societal arena, and the academic arena. The societal arena contains professionalized and traditional actors, a plethora of civil society and interest organizations, consultancy firms, and the media and the wider public.

While all institutionalized things take time to change, or are even resistant to change, the Dutch policy advisory system has started to shift towards greater diversification. It has begun to feel the influence of internationalization, and in particular the Europeanization of advising (Van den Berg, 2017). More general trends to which the Netherlands also is exposed include the pluralization and externalization of policy advice (Craft \& Howlett, 2013). Van den Berg (2017) found a clear trend among senior civil servants in the Netherlands, towards relying increasingly on external advisors, including official councils, consultancy firms, and university-based research institutes. The country has innumerable consultancy firms, which is a sign that there is a considerable market for such. Furthermore, increasing pressure on government has given rise to a number of informal advisory committees (Schulz et al., 2008). A comparative study of policy advisory systems in OECD countries shows that the Netherlands is at the short end of the scale of longevity of ad hoc committees-most of which last less than a year (OECD, 2017: 34).

While many arrangements have resulted in the 'scientification of politics', the opposite trend, meaning the increasing politicization of science, is also visible (Weingart, 1999). In February 2017, the Chamber of Representatives adopted a motion requesting the Royal Netherlands Academy of Arts and Sciences to investigate the extent to which the 'independence of science' is threatened within academia, as one view held that 
social scientists had leftist political preferences. In 2018, the Academy concluded that such a threat was not clearly grounded (Royal Netherlands Academy of Arts and Sciences, 2018).

As a result of all of these developments, we may conclude that the boundaries between government organizations, the external environment and the academic sphere, have become more fluid in recent years. (see also Timmermans et al., 2021). The policy-making system of the Netherlands has always included a structural form of intensive cooperation between policy makers and experts. However, this has recently become more diversified and has also moved beyond the existing formal structures, making interactions less predictable.

\subsubsection{Expectations on the Advisory Roles of Political Scientists}

Political scientists in the Netherlands thus have an increasing range of institutional and extra-institutional windows in which to interact with policy makers. This is a mutual situation: political scientists, like other academic experts, may seek such access to the policy-making domain and social debate, but they also are invited to, or sometimes actively drawn into, those spheres. The institutional shift in public task performance has involved a growing need for external advice on the part of both government departments, that have witnessed something of a policy-making 'brain drain', and private and semi-private organizations embracing new tasks (Van den Berg, 2017).

The four ideal types of political scientist differ from one another in their spheres of activity. An opinionating scholar may be oriented, in the main, towards media channels in an attempt to divulge the messages concerned to a broad audience. A true opinion maker, on the other hand, engages in such external activity relatively frequently. So does the public intellectual, but this role type implies more external 'multitasking': both opinionating and providing advice to policy makers. Comparatively, the expert may be oriented more towards policy-making institutions and different types of recipient within, or related to, such.

Considering the traditional features and the changing aspects of the Dutch policy advisory system and the general characteristics of political science in the Netherlands, we can posit several expectations with regard to the advisory roles of scholars. Firstly, while all of the aforementioned types may be present in the Netherlands, we would expect experts and opinionating scholars to be much more frequently so. In line with other 
consensus-style regimes, political scientists may be expected to engage relatively strongly in policy advising, as they have multiple access points facilitating interaction with policy makers. Thus we would expect the role of expert to occur frequently. However, we also expect a large number of political scientists to engage in providing opinionated advice, either close to or at some distance from policy-making institutions. We attribute this mainly to the more open, diversified nature of exchanges between political scientists and policy makers, which lowers the threshold for engaging in normative phronesis. Moreover, the political affiliations of certain political scientists may also trigger this type of activity. We would assume that scholars who are not involved in policy advising at all, but who operate as pure academics only, are mainly going to be younger scholars who are not (yet) known in formal policy advisory arenas, and who feel pressurized into prioritizing fundamental research and developing their teaching portfolios. Overall, however, we would expect the pure academic to be less prominent in the Dutch sample. The public intellectual-the 'all-inclusive' role type-is expected to be found less frequently, but to be comparatively more visible than in other countries.

As mentioned earlier, the Dutch political science community is segmented, with public administration existing next to political science departments. While we cannot make any broad generalizations here, our next expectation is that the community of public administration scholars is relatively more oriented towards the role of expert, as their specific field emerged precisely in order to provide a knowledge base and source of education for public administration practitioners. For those indicating political science as their primary domain, we expect them to be more likely within the opinionating category of scholars engaging in advising on their specific areas of study: political parties, the electorate, and European and world politics. This opinionating role, moreover, may be driven by increased diversity and an increasing number of cases of politicization.

\subsection{Policy Advising and Public Engagement by Dutch Political Scientists}

Based on the typology presented in Chap. 2, we now present and discuss the findings for the Netherlands. We also present findings on the general estimation of the social or political relevance and impact of the discipline, and on the extent to which Dutch political scientists appear in the media, 
and in what roles. The viewpoints and activities of scholars in Dutch academia are measured and analysed in regard to organizations with policy responsibility, or seeking to influence public policy, and/or the media and public opinion.

Totally $18.6 \%$ ( 85 respondents) of the population of political scientists working at a university institute in the Netherlands filled in the survey questionnaire. These respondents represent a mix of ages, and hence also seniority, with the youngest respondent born in 1989 and the oldest in 1946. The average age of respondents was 44.8 , which is slightly younger than the overall average in the project as a whole ( 46 years). Furthermore, $27.4 \%$ of Dutch respondents were female, and $69 \%$ men $(3.6 \%$ preferred not to disclose their gender, or did not respond to this question). This is in keeping with the gender distribution of the total population of political scientists that received the survey in the Netherlands $(31 \%$ females, $69 \%$ male).

\subsubsection{Estimated Visibility and Impact}

Dutch political scientists consider themselves to be publicly visible and also capable of achieving a social and political impact. The country is among the ten countries with the highest level of self-estimated visibility in public debate, and in the top three in terms of estimated impact. More than $50 \%$ of the respondents think that political science has a real impact on society and politics. This visibility and impact is about social and political relevance, rather than professional (training political scientists for future jobs) or civic relevance (engaging with civil society) (Senn \& Eder, 2018: 5-6). Political relevance connects most closely to policy advising.

\subsubsection{Engagement in Different Types of Advisory Activity}

If we focus on the frequency of advisory activities, we see certain differences between the types of advice provided by Dutch political scientists. Weekly activity is something of an exception, although some activities happen regularly while others are rarely witnessed, as can be seen from Table 13.1.

The findings indicate that evaluations are provided less frequently-and probably by fewer political scientists - than are analyses, explanations, or advice on policy alternatives. Conducting evaluations also comes with a particular methodological toolkit not familiar to all political scientists. 
Table 13.1 Frequency and type of advice $\%(N)$ - the Netherlands

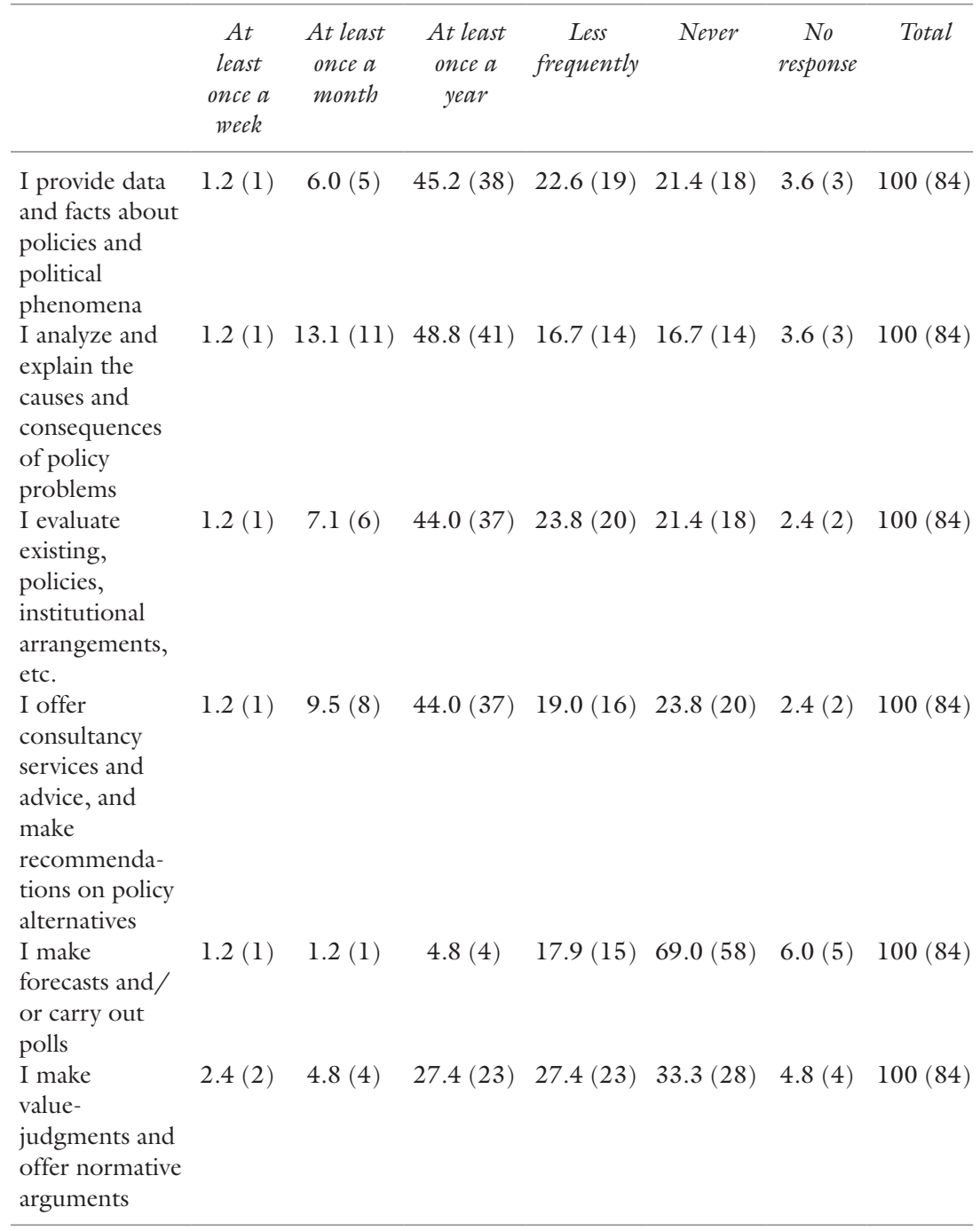

Source: ProSEPS survey data

Note: Question: 'How often, on average, during the last three years, have you engaged in any of the following advisory activities with policy actors (policymakers, ministry officials, interest groups, political parties, etc.)?" 
Also making value judgements and normative arguments happens, on average, no more than once a year or less. Comparatively, however, normative discourse is less often excluded from the scope of activities than on average for all the countries included in this study, where almost $44 \%$ of respondents never reach out in this way. Likewise, consultancy services are offered more frequently in the Netherlands. By and large, the threshold for advisory activities seems to be once per year, with part of the political science community performing such roles more often, but a larger part of the respondents doing so less often. The least frequent activity of all is the specialized activity of polling and forecasting, which is only performed on a regular basis by a small number of political scientists, as is the case in most countries.

Turning to a more in-depth analysis of the profile of political scientists who engage in policy advisory activities, we find the compartmentalized nature of the community in this field represented in the focus of scholars. While a majority believe that they are first and foremost focused on political science matters, almost half of the respondents mention public administration, and one-third deal with public policy. These choices are not mutually exclusive, but they show the different orientations of scholars in the Netherlands, which are also institutionalized in academic departments. Specialized foci are rarer: specific policy domains are the primary territory of few political scientists engaged in advisory activities as can be seen from Table 13.2. The prominence of public administration stands out: the

Table 13.2 Sub-disciplinary areas of political scientists (\%) — the Netherlands

\begin{tabular}{lr}
\hline Political science & 53.6 \\
Public administration & 44.1 \\
Public policy & 33.3 \\
Social policy and welfare & 10.7 \\
Environmental policy & 9.5 \\
Urban studies & 6.0 \\
Gender studies & 3.6 \\
Economics & 3.6 \\
Health policy & 2.4 \\
Environmental science & 2.4 \\
Finance & 1.2
\end{tabular}

Source: ProSEPS survey data

Note: Question: 'Which categories best describe your area(s) of expertise? Please select the three main categories.' 
Table 13.3 Substantive focus of policy advice (\%) — the Netherlands

\begin{tabular}{lrlr}
\hline $\begin{array}{l}\text { Government and public administration } \\
\text { organization, electoral reform }\end{array}$ & 51.2 & Technology & 6.0 \\
$\begin{array}{l}\text { International affairs, development aid, } \\
\text { EU }\end{array}$ & 28.6 & Health & 6.0 \\
Social welfare & 16.7 & Public works, urban planning & 6.0 \\
Immigration, integration, ethnic & 15.5 & Agriculture, food policy & 4.8 \\
minorities & & & \\
Civil rights, political rights, gender issues & 13.1 & Macro-economics, monetary & 2.4 \\
& & policy, industry policy & \\
Environment & 13.1 & Energy & 2.4 \\
Education & 7.1 & Culture & 2.4 \\
Labour & 6.0 & Transportation & 1.2 \\
Crime, law and order & 6.0 & Foreign trade & 1.2 \\
Defence & 6.0 & & \\
& & & \\
\end{tabular}

Source: ProSEPS survey data

Note: Question: 'With which substantive policy areas is your advice concerned?'

percentage is more than twice the average for all countries included in the survey $(21 \%)$.

While the disciplinary focus is mainly on political science, public administration and public policy also offer advisory activities in regard to many different topics. This is clear from Table 13.3, which illustrates the substantive focus of policy advice.

Matters of government structure and functioning, and of international affairs and EU governance, represent the topics most widely focused on by political scientists. These are their areas of expertise par excellence. However, their advisory activities also concern a number of other topics, such as social welfare, immigration, civil rights, and the environment, and to a much lesser degree a variety of other policy issues. The issue of social affairs is third in the ranking, after domestic and international political structure and process, of those areas in which political scientists are most active. Generally, social policy is the most external advice-taking domain in the Netherlands (van den Berg, 2017: Table 4) and political scientists thus take their place in it. The increasingly contested, publicly debated nature of some policy topics, such as immigration, rights, and environmental concerns, have also opened the way for the involvement of political scientists (Timmermans \& Scholten, 2006). However, while political scientists have a knowledge primacy regarding general domestic or international governmental issues, they are usually not experts on other topics on the 
political agenda. This is corroborated by the findings in Table 13.2. The advisory roles of political scientists mostly concern how these issues may pose challenges in terms of governance, and how political structures and processes addressing such challenges are to be understood and strengthened. In other words, political science-based advising on issues is often more about the process than about specific content. This reflects the body of knowledge and skills of academic political scientists.

\subsubsection{Recipients and Channels of Advice}

The civil service features prominently in advisory interactions with political scientists, as Table 13.4 below shows. Civil servants in the Netherlands have come to rely increasingly on external advice (van den Berg, 2017): this category of advice is actually an umbrella for all kinds of advisory interaction, both formal and informal, consisting of longer or permanent arrangements, as well as those of a more ad hoc nature.

The types of recipients of advice do not correspond exactly to specific types of advice, such as official or unofficial, permanent or temporary, arrangements with political scientists, and so on. Thus, for example, advisory bodies, which are second in order of prominence, may officially employ political scientists part-time, or they may simply call on them occasionally. The same applies to civil society organizations, think tanks, and all other types of recipient. The fact that only just over fourth quarter of political scientists engage with political parties for advisory purposes stands

Table 13.4 Recipients of advice (\%)—the Netherlands

\begin{tabular}{ll}
\hline Civil service & 66.7 \\
Advisory bodies & 57.1 \\
Other civil society organizations and citizen groups & 53.6 \\
Think tanks & 40.5 \\
Executive politicians & 35.7 \\
International organizations & 32.1 \\
Legislative politicians & 29.8 \\
Political parties & 27.4 \\
Private interest groups & 26.2 \\
\hline
\end{tabular}

Source: ProSEPS survey data

Note: Question: 'With which actors have you engaged in knowledge exchange, advisory or consulting activities over the last three years?' 
in contrast to the large number of parties in the Netherlands and the affiliations that many political scientists have with them.

The most important conclusion that can be drawn from Table 13.4 must be seen in a comparative perspective: with the exception of political parties and legislative politicians, all types of recipients of advice in the Netherlands have higher, in some cases much higher, percentage scores than the average scores taking all countries into consideration. This finding empirically illustrates the density of advisory arrangements, the diversity of its forms, and as we shall see below, the orientation of scholars towards advising and outreaching. The fact that political science academics advise parties and legislators to only a modest degree may tell us something about the perception that the Dutch parliament has of political scientists in regard to the policy process or about the perception held in parliament of political scientists acting in advisory roles in the Netherlands. Private interest groups may be the least expected counterparty in advisory situations, but interaction with such groups is nevertheless more frequent in the Netherlands than it is in many other countries.

The different recipients, both inside and outside the formal institutions of government, are provided with a broad range of channels for interaction with experts in the Dutch policy advisory system. Formal channels are more frequently used by political scientists in the Netherlands than on average. Political scientists, however, also engage in informal knowledge exchange, although hardly anyone uses such channels alone, as Table 13.5 reveals. The data in this study are not time series data, and so we cannot be certain, but it would seem that the many mentions of both formal and

Table 13.5 Formality/informality of advice $\%(N)$-the Netherlands

\begin{tabular}{lc}
\hline & $\%(N)$ \\
\hline Entirely informal & $1.3(1)$ \\
Mainly informal & $22.1(16)$ \\
Both formal-informal & $52.6(40)$ \\
Mainly formal & $17.1(13)$ \\
Entirely formal & $7.9(6)$ \\
Total & $100(76)$ \\
\hline
\end{tabular}

Source: ProSEPS survey data

Note: Question: 'Please, rate your engagement in direct knowledge exchange, advisory or consulting activities, over the last three years, on a scale from entirely informal (e.g. personal talks) to entirely formal (e.g. appointment to advisory committees, expert councils, etc.).' 
informal channels point to an ongoing trend towards pluralism and the opening of external channels for advice and advocacy. However, it should be pointed out that also traditional channels in neo-corporatist structures in the Netherlands involve a level of informal boundary work between knowledge producers and knowledge users. The aforementioned prominence of the Dutch civil service as a recipient of advice also involves both formal and informal channels.

It is not always possible to distinguish between formal and informal advice by looking at the specific channels used. The most commonly used way of providing knowledge to recipients is via publications $(57 \%$ of the sample mentions doing so at least once a year), which is also the most commonly used outlet in all countries when a frequency of 'at least once a year' is taken as a threshold. This, however, is the least typical channel for advising activities as it is part of the regular academic work of scholars. Research reports are the next most frequently used channel (50\%) and are functionally more distinctive in this respect, while the drafting of policy reports, briefs, and memos is an even more characteristic advisory activity and is mentioned by almost $41 \%$ of the respondents who had already indicated that they engage in advisory work. Blog writing and social media contributions (just over 40\%) and traditional media articles (39\%) are other external advisory channels aimed at a broader audience. Given that such activities usually require less preparation time than do more academic publications, they are used somewhat more regularly, several times a year in fact, by a significant share of the respondents. As mentioned, the Netherlands is one of the countries with the highest estimated visibility of political scientists. A substantial number of them indeed state that they occasionally or regularly participate in public debates in the media.

The most distinctive way of transferring knowledge to policy makers and other practitioners in the Netherlands, however, is by providing training courses or sessions, which happens more frequently in this country than elsewhere. Some ministries, such as the Ministry of Finance, have established their own training institutes ('National Academy for Finance and Economics'), where political scientists (mainly public administration scholars) give classes. The Netherlands School of Public Administration is another organization providing executive training for civil servants. Almost half of the Dutch respondents indicated that they engage in training at least once a year, compared to an average of $38 \%$ for all countries. Advice is also provided through face-to-face contact, partly combined with the channels above, and partly during workshop sessions or conferences. 


\subsubsection{Reasons for Engaging in Advisory Activities}

What are the underlying reasons for engaging in advisory activities? Table 13.6 reveals that an overwhelming majority of political scientists consider advising as making an important contribution to society.

Table 13.6 Intrinsic and extrinsic motives for engaging in policy advisory and consulting activities $\%(N)$-the Netherlands

\begin{tabular}{|c|c|c|c|c|c|c|}
\hline & $\begin{array}{c}\text { Not } \\
\text { important } \\
\text { at all }\end{array}$ & $\begin{array}{c}\text { Somewhat } \\
\text { unimportant }\end{array}$ & $\begin{array}{l}\text { Somewhat } \\
\text { important }\end{array}$ & $\begin{array}{l}\text { Absolutely } \\
\text { important }\end{array}$ & $\begin{array}{l}\text { No } \\
\text { response }\end{array}$ & Total \\
\hline $\begin{array}{l}\text { Engagement } \\
\text { in advisory or } \\
\text { consulting } \\
\text { activities helps } \\
\text { advance my } \\
\text { academic } \\
\text { career }\end{array}$ & $17.8(15)$ & $40.5(34)$ & $26.2(22)$ & $3.6(3)$ & $11.9(10)$ & $100(84)$ \\
\hline $\begin{array}{l}\text { Engagement } \\
\text { in advisory or } \\
\text { consulting } \\
\text { activities helps } \\
\text { expand my } \\
\text { career options } \\
\text { and provides } \\
\text { alternative } \\
\text { sources of } \\
\text { finance }\end{array}$ & $23.8(20)$ & $27.4(23)$ & $32.1(27)$ & $5.9(5)$ & $10.7(9)$ & $100(84)$ \\
\hline $\begin{array}{l}\text { Engagement } \\
\text { in advisory or } \\
\text { consulting } \\
\text { activities is } \\
\text { part of my } \\
\text { professional } \\
\text { duty as a } \\
\text { political } \\
\text { scientist }\end{array}$ & $5.9(5)$ & $11.9(10)$ & $39.3(33)$ & $30.9(26)$ & $11.9(10)$ & $100(84)$ \\
\hline $\begin{array}{l}\text { I like to make } \\
\text { a contribution } \\
\text { to society }\end{array}$ & $1.2(1)$ & $1.2(1)$ & $25.0(21)$ & $60.7(51)$ & $11.9(10)$ & $100(84)$ \\
\hline $\begin{array}{l}\text { I like to stay } \\
\text { active-minded }\end{array}$ & $14.3(12)$ & $4.7(4)$ & $36.9(31)$ & $28.6(24)$ & $15.5(13)$ & $100(84)$ \\
\hline
\end{tabular}

Source: ProSEPS survey data

Note: Question: 'How important are the following reasons for your engagement in advisory or consulting activities?’ 
A substantial number of scholars also consider it part of their professional duties. For many, advising is important to stay active-minded. Most Dutch political scientists do not engage in advising for the purpose of advancing their careers, although it is seen to offer opportunities for the expansion of career options and research funding.

When asked about their motives for engaging in public debate, almost all political scientists considered this a part of their role. This is consistent with the aforementioned sense of professional duty, which is also high. The majority still think that academic outlets should be tested before engaging in public debate. Again, this conforms to the perception of professional duty more generally, while a strong scientific knowledge base is considered important (Table 13.7).

Table 13.7 Normative views on policy advice $\%(N)$ —the Netherlands

\begin{tabular}{|c|c|c|c|c|c|c|}
\hline & $\begin{array}{l}\text { Fully } \\
\text { agree }\end{array}$ & $\begin{array}{c}\text { Somewhat } \\
\text { agree }\end{array}$ & $\begin{array}{c}\text { Somewhat } \\
\text { disagree }\end{array}$ & $\begin{array}{c}\text { Fully } \\
\text { disagree }\end{array}$ & $\begin{array}{c}\text { No } \\
\text { response }\end{array}$ & Total \\
\hline $\begin{array}{l}\text { Political scientists } \\
\text { should engage in } \\
\text { public debate since } \\
\text { this is part of their } \\
\text { role as social } \\
\text { scientists }\end{array}$ & $52.4(44)$ & $41.7(35)$ & $4.7(4)$ & $1.2(1)$ & $0(0)$ & $100(84)$ \\
\hline $\begin{array}{l}\text { Political scientists } \\
\text { should engage in } \\
\text { public debate } \\
\text { because this helps } \\
\text { them to expand } \\
\text { their career options }\end{array}$ & $1.2(1)$ & $29.7(25)$ & $35.7(30)$ & $26.2(22)$ & $7.1(6)$ & $100(84)$ \\
\hline $\begin{array}{l}\text { Political scientists } \\
\text { should engage in } \\
\text { media or political } \\
\text { advisory activities } \\
\text { only after testing } \\
\text { their ideas in } \\
\text { academic outlets }\end{array}$ & $28.6(24)$ & $28.6(24)$ & $30.9(26)$ & $9.5(8)$ & $2.4(2)$ & $100(84)$ \\
\hline
\end{tabular}

Source: ProSEPS survey data

Note: Question: 'To what extent do you agree with the following statements?' 


\subsection{Types of Scholars in Advising}

The variables presented and discussed thus far underlie the construction of the four main types of advisory role, from the pure academic who refrains from any kind of such activity to the public intellectual for whom engagement is all-inclusive.

When considering the occurrence of advisory types, the Dutch picture resembles the average in the larger European sample only for the categories of experts and public intellectuals. Table 13.8 shows that $28.6 \%$ of the political scientists responding to the survey are experts, slightly more than the European average. The different recipients of advice lie both within the government apparatus and also in external arenas and at intersections where evidence is central in the modus operandi of the various advisory bodies. Hence we can distinguish between government-oriented experts and external arena-oriented experts. Just under $5 \%$ are public intellectuals, which is marginally above average for all countries. Not surprisingly, it is quite rare to find political scientists taking a highly active role in a diverse range of advisory activities, from formal advising to opinionating in external arenas and the media. Most scholars engage in advisory activities in this field to a certain extent, although it is not their call to be active in such.

The opinionating role is the one most frequently adopted overall, particularly in the Netherlands. We note that the opinionating role is a broad category, and the frequency of activities actually determines whether we can truly speak of an opinion maker, or rather of the political scientist playing a more modest and cautious role as an occasional voice helping with the interpretation of matters on the public or political agenda.

The relatively large number of opinionating political scientists in the Netherlands contrasts with the comparatively small proportion of political

Table 13.8 Proportion of advisory role types - the Netherlands

\begin{tabular}{lccc}
\hline Ideal type & $\begin{array}{c}\text { Total number in the } \\
\text { Netherlands }\end{array}$ & $\begin{array}{c}\text { Percentage in the } \\
\text { Netherlands (\%) }\end{array}$ & $\begin{array}{c}\text { Percentage in the } \\
\text { overall sample (\%) }\end{array}$ \\
\hline Pure academic & 8 & 9.5 & 20.3 \\
Expert & 24 & 28.6 & 26.6 \\
Opinionating scholar & 48 & 57.1 & 48.7 \\
Public intellectual & 4 & 4.8 & 4.4 \\
\hline
\end{tabular}

Source: Author

Note: Types operationalized on the basis of the content and frequency of advice (see Chap. 3 ) 
scientists who define themselves as pure academics. Less than $10 \%$ see themselves in this latter category, compared with over 20\% in the European sample as a whole. The solid anchorage of many science-policy interfaces in the Netherlands provides ample opportunities for policy advising, which almost all political scientists seem to resort to with a certain frequency. Admittedly, self-selection may have reduced the number of pure academics in our sample. Scholars who do not engage in any type of advising may have chosen not to participate in the survey. There is no reason, however, to believe that such self-selection was more frequent than in the other countries concerned.

The findings regarding role types thus confirm our expectation that there are more experts and opinionating scholars in the Dutch sample than elsewhere. In terms of experts, the difference from the European sample is very small, whereas it is more pronounced in the case of opinionating scholars. Tendencies in the Dutch policy advisory system may partly account for this: the boundaries of the advisory system have become more permeable, and interpretation, opinionating, or advocacy by political scientists happens not only in formal arenas but also in informal and public arenas. Affiliation to political parties may also be conducive to such activities. Public intellectuals, however, are a small minority within the academic political science community. Comparatively speaking, their occurrence seems related to the degree of institutionalization of academic political science: in smaller countries without such institutionalization public intellectuals are more numerous. The context is different in the Netherlands.

The expert and opinionating roles also reflect the topics on which political scientists advise. The main such topics (general structures, reforms and operations of government, and international or European matters-) appear particularly prominent among opinionating political scientists. They are less the focus of attention of the experts, and public intellectuals, who tend to concentrate specifically on immigration, rights, and education. Experts and opinionating scholars also advise on other policy topics and differ as to which ones they focus on. Experts advise on matters concerning the environment, agriculture, and food, as well as certain specific social policies and labour-related topics, while (more or less active) opinionating scholars advise on social welfare, civil rights, immigration, and, occasionally, defence matters and public works. While experts seem to specialize, opinionating scholars advise on the broadest range of topics, with only agriculture and food policy (an expert domain) remaining outside of their domain. 


\subsubsection{Age, Gender, and Role Types}

The age of scholars appears to differ considerably with role types: experts (with an average age of 42.7) and opinionating political scientists (average age of 47.8) in the Netherlands tend to be older than pure academics (38.1) and public intellectuals (36.8). The younger age of pure academics is not surprising, as younger scholars are under considerable pressure to perform academically, and they may also not have obtained access to, and taken advantage of, the full range of advisory venues and channels. However, the fact that public intellectuals on average are almost the youngest category is rather remarkable. Although the limited number of scholars falling into this category should be interpreted cautiously, a small group of younger academics has decided to go 'all the way' and use every opportunity to engage with policy makers and other practitioners. While this age-role type combination is very unusual, it is also an exception, as the two largest groups of political scientists-the experts and the opinionating scholars - are on average in their mid-40s. In particular, an opinionating role appears to reflect academic experience. This is also the largest category of scholars, thus telling us something about the career paths developed prior to performance of this type of external activity. In the case of the experts, this applies to a lesser extent. While there is thus clear variation in the age-role type relationship, we note that the average ages in the Dutch sample (between 36 and 48 for the different role types) also follow our selection criteria in the survey: all scholars in the sample have obtained their PhD. For still younger scholars the pattern may be somewhat different, as it is likely that advisory and other external activities come with steps up in their academic careers.

While political science in the Netherlands is a field numerically dominated by men (over two-thirds of respondents declaring their gender were men), female scholars are represented in each of the advisory types. Compared to the European sample, the pure academic and the public intellectual categories contain more female scholars in the Netherlands, precisely $50 \%$ of the total. Again, these are percentages representing relatively small absolute numbers. What stands out most is that for the larger categories of experts and opinionating political scientists, female scholars are underrepresented. Women in political science academia engage in opinionating in the Netherlands even less than in the European sample as a whole. Opinionating in the field of political science in the Netherlands is 
thus very much a male activity. This is true to a lesser extent in the case of those political scientists within the expert category.

To conclude, advisory roles in the Netherlands in the field of academic political science tend to be age-dependent. We expected pure academics to be younger than their more active advisory colleagues, and our findings confirm this with the one surprising exception of the small group of public intellectuals. However, advising is even more strongly gender dependent. Changes in the policy advisory system and political and social processes, that draw more political scientists into advisory roles, seem to affect male scholars more than female scholars in the Netherlands.

\subsubsection{A Segmented Discipline and Advisory Roles}

We expected public administration scholars to be relatively more active in the role of experts, and political scientists more in that of opinionating scholars. Public administration includes (or is adjacent to) public policy, which is a part of the discipline that directly targets policy makers in many domains. The distribution of the policy topics focused on shows that experts and opinionating scholars place a different emphasis on the domains in which they provide advice. Likewise, when looking at the academic background of the experts and opinionating scholars, as shown in Table 13.9, public administration appears less the exclusive preserve of the experts than expected. There is a greater difference between political

Table 13.9 Proportion of advisory roles by sub-disciplinary focus (\% by type)the Netherlands

\begin{tabular}{lccc}
\hline Sub-disciplinary focus & Expert & Opinionating scholar & Public intellectual \\
\hline Political science & 50.0 & 60.4 & 100 \\
Public administration & 45.8 & 50.0 & 50.0 \\
Public policy & 41.7 & 35.4 & 25.0 \\
Social policy and welfare & 4.2 & 16.7 & 0.0 \\
Environmental policy & 12.5 & 10.4 & 0.0 \\
Urban studies & 4.2 & 8.3 & 0.0 \\
Gender studies & 4.2 & 4.2 & 0.0 \\
Economics & 4.2 & 4.2 & 0.0 \\
Health policy & 8.3 & 0.0 & 0.0 \\
Environmental science & 8.3 & 0.0 & 0.0 \\
Finance & 0.0 & 2.1 & 0.0 \\
\hline
\end{tabular}

Source: ProSEPS survey data 
science and public policy as the indicated primary discipline. Political science throws up relatively more opinionating scholars, and also includes all public intellectuals. In turn, those scholars with a background in public policy more often fall into the expert category of advisor: these findings are in keeping with our expectations. While public administration is less a distinguishing feature of advisory role type, the related disciplinary area of public policy contains more experts. Moreover, opinionating scholars generally have a broader background than experts, who tend to come more from specific parts of the discipline. This confirms the expectation that experts will be specialized to a relatively greater degree also in their own subjects.

Thus, while in recent decades, political science and public administration have evolved as relatively independent segments of Dutch academia, the effects of this segmentation on the types of advisory role have been limited. There are more visible similarities between the types of advisory role performed by scholars in political science and public administration (and public policy) than there are differences. The specific objects of research, and consequently of advice, may vary between them, but the nature of engagement that emerges from our study seems to point to a future of integration between parts of the discipline.

\subsection{Discussion And Conclusion}

The advisory activities of political scientists in the Netherlands must be understood within the context of the Dutch policy advisory system as a whole. Compared to other consensus-style countries, the advisory landscape has become increasingly diversified, with a strongly institutionalized role being played by boundary organizations bridging science and policy making, but also new actors appearing in the diverse arenas of knowledge exchange (Pattyn et al., 2019). The Dutch advisory system displays an increasing degree of overlapping and interaction between government, academia, and the public sphere. These developments mean that political scientists now have a range of formal and informal windows for providing policy advice, either reactively on demand or more proactively on their own initiative. Figure 13.1 places political scientists within the Dutch policy advisory system.

Against this evolving institutional and cultural background, it is no surprise to find that an overwhelming majority of Dutch political scientists $(90.5 \%)$ engages in policy advising in some way, and with a certain 


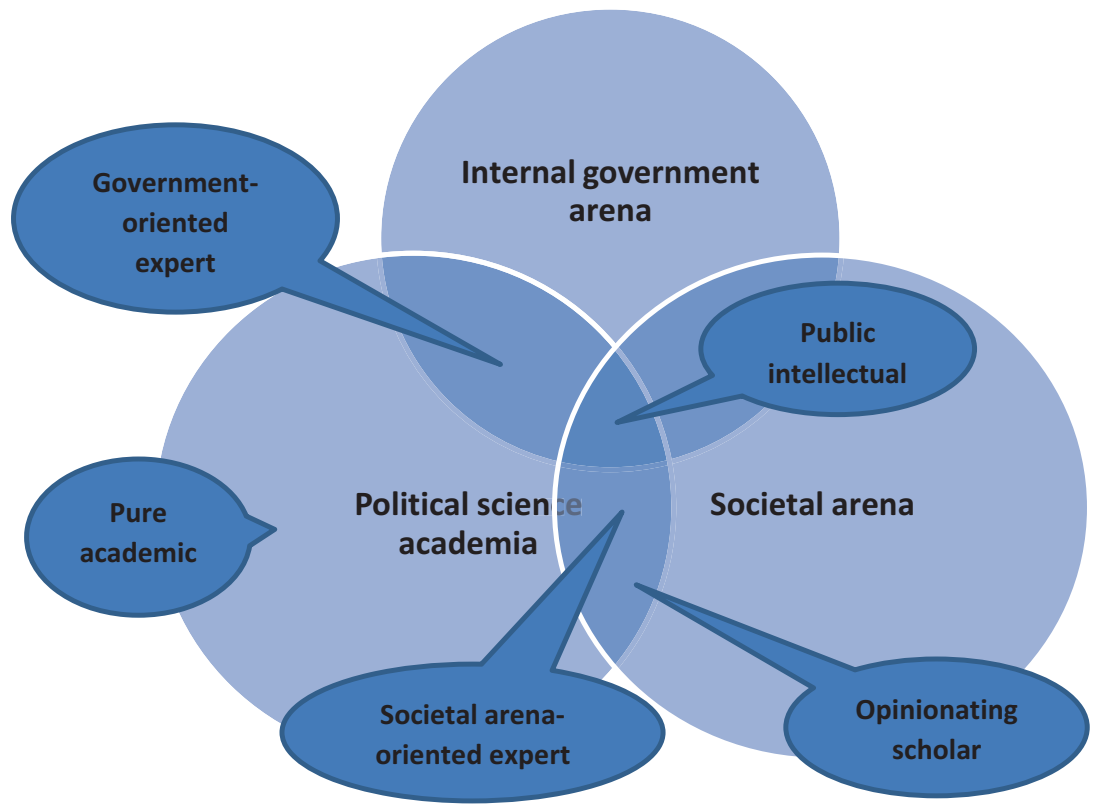

Fig. 13.1 Political scientists in the Dutch policy advisory system. Note: Adapted from Blum and Brans (2017: 348)

frequency. A considerable proportion of political scientists working in Dutch academia are international. In the present study we have not looked at the extent to which international scholars are involved in advisory roles. Part of advisory activity is conducted at international and European levels and deals with international issues. While this may imply involvement, another finding that emerged is that the majority of advisory activities are conducted at the domestic level, and to a lesser extent at the subnational level.

Political scientists working at Dutch universities perceive themselves as being highly visible and having a significant social and political impact. They mostly agree that engaging in policy advising has no distracting effect on career advancement and that their advisory work is part of their professional duties. For many, it also contributes towards making democracy and the policy process work better. The traditional characteristics of the Dutch policy advisory system lead us to expect a strong presence of 
experts. They are indeed visible, but those who stand out more are the opinionating political scientists. While the consensual policy advisory system is based on the logic of depoliticization and scientification, the prominence of opinionating scholars may point to an increasing degree of politicization of political science, or at least to the lowering of the thresholds for public interpretative and advocacy activities.

The ideal typical roles applied in the empirical analysis all contain some behavioural variation. Political scientists within a given role category do not all display the exact same behaviour. We have used a threshold for classifying scholars in terms of their advisory orientation and activities. Opinionating, which is the most frequently observed activity of political scientists, can vary from giving viewpoints or interpretations once or a few times a year, to real opinion making or even punditry. Thus the high percentage of political scientists within this category must be seen in nuanced terms. Likewise, what we call experts include both those political scientists with one or more permanent, prominent advisory positions and scholars bringing their knowledge to the table more occasionally, for the benefit of either government or external organizations involved in the policy process. We have classified scholars on the basis of their varying advisory roles and perspectives of such roles, but always within the context of their academic background. Political science scholars do not normally operate as consultants, news-makers, opinion leaders, or dedicated advocates of a cause. At the same time, the vast majority of political scientists are not the pure academic type sometimes stereotyped as the inhabitant of an ivory tower.

Our study also shows that thresholds exist for advisory engagement on the part of younger, and in particular female, political science scholars. Role perception and behaviour may be discretionary but are more likely to be formed by institutional or cultural conditioning. This finding and our findings in general are barely influenced by the segmented nature of political science in the Netherlands. Although separate departments of political science and public administration have co-existed side-by-side since the 1980s, the advisory profiles of scholars within these two areas of the discipline differ less than we expected. Public administration and public policy scholars only operate more in an expert capacity, and political scientists more in an opinionating capacity, to a certain extent.

Changes in the policy advisory system may be partly unrelated to the views and behaviour of academic communities such as that of political science, but also partly linked to what happens in such scholarly 
communities. Stability and changes within the domestic policy advisory system shape and reshape the advisory roles performed by scholars in any field of scientific knowledge. The Dutch system is now more pluralistic than before, with the 'lay arena' outside governmental organizations becoming more diversified and open, but also setting different criteria for the production, use, and legitimacy of knowledge. In this changing environment, political scientists may play a greater advisory role in the future. One issue that requires examining with the future in mind is how the questions of age and, in particular, gender play a part in the advisory aspects of political scientists' careers in the Netherlands.

\section{REFERENCES}

Blum, S., \& Brans, M. (2017). Academic policy analysis and research utilization in policymaking. In M. Brans, I. Geva-May \& M. Howlett (Eds.), Routledge Handbook of Comparative Policy Analysis (pp. 341-359). London: Routledge.

Craft, J., \& Howlett, M. (2013). The dual dynamics of policy advisory systems: The impact of externalization and politicization on policy advice. Policy and Society, 32(3), 187-197.

Crepaz, M. M., \& Lijphart, A. (1995). Linking and integrating corporatism and consensus democracy: Theory, concepts and evidence. British Journal of Political Science, 25(2), 281-288.

Halffman, W., \& Hoppe, R. (2004). Science policy boundaries: A changing division of labour in Dutch expert policy advice. In S. Maasse \& P. Weingart (Eds.), Scientific expertise and political decision making (pp. 135-152). Kluwer.

Hallfman, W. (2009). Measuring the stakes: The Dutch planning bureaus. In P. Weingart \& J. Lentsch (Eds.), Scientific advice to policy making: International comparison (pp. 41-66). Barbara Budrich Publishers.

Koens, L., Chiong Meza C., Faasse, P., \& de Jonge, J. (2016). Public knowledge organisations in the Netherlands. Facts and Figures. Rathenau Institute. Retrieved September 2, 2018, from https://www.rathenau.nl/sites/default/ files/2018-03/FF17_PKOs\%20in\%20the\%20Netherlands_WEB_0.pdf.

Lijphart, A. (2012). Patterns of democracy. government forms and performance in thirty-six countries ( 2 nd ed.). Yale University Press.

OECD. (2017). Policy Advisory Systems: Supporting Good Governance and Sound Public Decision Making. OECD Public Governance Reviews. OECD Publishing, Paris. https://doi.org/10.1787/9789264283664-en.

Pattyn, V., Blum, S., Fobé, E., Pekar-Milicevic, M., \& Brans, M. (2019). Academic policy advice in consensus-seeking countries: The cases of Belgium and Germany. International Review of Administrative Sciences. Online first. https://doi.org/10.1177/0020852319878780 
Pattyn, V., Pittoors, G., \& Van Hecke, S. (2017). Who are the political parties' ideas factories? On policy analysis by political party think tanks. In Routledge Handbook of Comparative Policy Analysis. Routledge.

Reinalda, B. (2007). The current state of political science in the Netherlands. In D. Klingemann (Ed.), The state of political science in Western Europe. Barbara Budrich Publishers.

Royal Netherlands Academy of Arts and Sciences. (2018). Vrijheid van wetenschapsbeofening in Nederland. KNAW: March 2018.

Scholten, P., \& van Nispen, F. (2015). Advisory board and planning bureaus. In F. van Nispen \& P. Scholten (Eds.), Policy Analysis in the Netherlands (pp. 139-154). The Policy Press.

Schulz, M., van Twist, M., \& Geveke, H. (2008). Besturen in Commissie: Verklaring van een Fenomeen. Beleid \& Maatschappij, 2, 94-106.

Senn, M., \& Eder, F. (2018). Cui Bono Scientia Politica? A multi-dimensional concept of relevance and the case of political science in Austria. Österreichische Zeitschrift für Politikwissenschaft, 47(3), 1-17.

Strassheim, H., \& Kettunen, P. (2014). When does evidence-based policy turn into policy-based evidence configurations, contexts and mechanisms. Evidence and Policy, 10(2), 259-277.

Timmermans, A., \& Scholten, P. (2006). The political flow of wisdom: Science institutions as policy venues in The Netherlands. Journal of European Public Policy, 13(7), 1104-1118.

Timmermans, A., van Rooyen, E., \& Voerman, G. (2015). Political party think tanks in the policy process. In F. van Nispen \& P. Scholten (Eds.), Policy Analysis in the Netherlands (pp. 187-202). University of Bristol Policy Press.

Timmermans, A., Pattyn, V., \& van der Meulen, B. (2021). Political and social forces shaping political science research and knowledge transfer in the Netherlands. In R. Eisfeld \& M. Flinders (Eds.), Political Science in the Shadow of the State: Research, Relevance, Deference (pp. 179-202). Palgrave Macmillan.

van den Berg, C. F. (2017). Dynamics in the Dutch policy advisory system: Externalization, politicization and the legacy of pillarization. Policy Sciences, 50(1), 63-84.

van Nispen, F., \& Scholten, P. (2015). Policy analysis in the Netherlands: An introduction. In F. van Nispen \& P. Scholten (Eds.), Policy Analysis in the Netherlands (pp. 1-14). The Policy Press.

Weingart, P. (1999). Scientific expertise and political accountability: Paradoxes of science in politics. Science and Public Policy, 26(3), 151-161. 
Open Access This chapter is licensed under the terms of the Creative Commons Attribution 4.0 International License (http://creativecommons.org/licenses/ by $/ 4.0 /$ ), which permits use, sharing, adaptation, distribution and reproduction in any medium or format, as long as you give appropriate credit to the original author(s) and the source, provide a link to the Creative Commons licence and indicate if changes were made.

The images or other third party material in this chapter are included in the chapter's Creative Commons licence, unless indicated otherwise in a credit line to the material. If material is not included in the chapter's Creative Commons licence and your intended use is not permitted by statutory regulation or exceeds the permitted use, you will need to obtain permission directly from the copyright holder. 